\title{
The Online Islamic Media Journalism in Indonesia: The Trend Analysis of Political News
}

\author{
Ali Nurdin \\ Communication Studies Program \\ Faculty of Da'wah and Communication \\ UIN Sunan Ampel \\ Surabaya, Indonesia \\ ali.nurdin@uinsby.ac.id
}

\begin{abstract}
The development of information technology through the internet network has led online media to be fast, efficient, and practical in informing the news to the public. There are online Islamic media that exist to spread facts and political opinions. The purpose of this study is to explain and describe the trends of online political news of Islamic media of eramuslim.com, islampos.com, and voice-islam.com. The analysis of this research uses Van Dijk model discourse which describes the tendency towards political news which is analyzed through six elements namely thematic, schematic, semantic, syntactic, stylistic, and rhetorical structures in the political news of online Islamic media. The results of this study shows the percentage of the online Islamic media has a tendency towards the theme of national political news of $51.91 \%$ and $48.09 \%$ of non-political news. In addition, the tendency towards national political news at eramuslim.com is $66.02 \%, 38.02 \%$ at islampos.com, and $57.89 \%$ at voice-islam.com. News schemes for summary are displayed without news leads, and news stories are more likely to be based on opinions rather than facts. The semantic structure is displayed through background, details, and intent of news that has a tendency to put political news as the opposition by displaying the opinion of certain political actors, whereas the syntactic structure is displayed through the form of active sentences continuously questioning the government policy of political actors without considering the $5 \mathrm{~W}+1 \mathrm{H}$ aspects in the news. Moreover, the stylistic structure of the word choice tends to use active sentences and be in an oppositional stance to the government in accordance with the ideology of the news media. By displaying images as a form of political affirmation emphasis, the rhetorical structure of the political news of online Islamic media is delivered with bold headlines with large size letters.
\end{abstract}

Keywords - journalism; islamic media; online media; tendency of political news; discourse analysis

\section{INTRODUCTION}

There is a significant displacement of media usage by the public in the era of industrial revolution 4.0. Five years ago, the public was still very faithful reading the print media as the main entrance of information and important news. However, the public now has started to leave the print media and move to online media. This phenomenon is certainly interesting in media business studies. The print media will gradually be neglected by the loyal readers because they move to online media.

Online media is the best choice for the public along with the development of information technology. Industrial Revolution 4.0 presents an interdisciplinary study of science as the basis for the study of the merger of cyber-physical systems. This system offers the creation of new values in both virtual world and real world [1].

Online media journalism is more practical than print media journalism [2]. Print media journalism takes time in designing and printing news. In covering the events, online media journalism can report repeatedly about events on the spot according to the fact development that occurs within 24 hours.

The development of mainstream online media sites has inspired the development of online media sites which have special ideological character. In Indonesia there are online media sites namely Islamic Media Online. Based on research results of Islamic Media Online site; Islamcendekia.com, there are five most popular Islamic sites in Indonesia namely Islamcendikia.com, Eramuslim.com, Islampos.com, Suaraislam.com, and MuslimDayly.net. These five online Islamic media sites that later became a reference for researchers to be more interested and more focused in conducting research on the construction of online political in news online Islamic media.

Political news becomes a magnet in all kind of news. It is as a fuel of all the media including online media with Islamic ideology. It is an information related to the delivery of messages which has political character by political actors to other parties [3], in the form of sharing of symbols, ideas, intentions, interests and so on among a number of political parties, political talks related to the interests of power, talk of influence (affecting people without threat), and authority talks (commandment) [4].

This research was conducted on the basis of the phenomenon argument, first; in general Islamic mainstream media has an Islamic ideology in reporting news, information, and opinions. The ideology embedded in this media will always color the news, information, and media opinion. Second, political news is as a standard to see how the ideology 
of Islamic media coloring every media coverage. Third, Indonesia as a developing democracy country places political news as a national news reference.

Based on the above research argument, this study is very interesting to be conducted to explain and to describe the trend of online political news of Islamic media in eramuslim.com, islampos.com, and suara-islam.com.

\section{Political News in Online Media Frame}

\section{A. Online Islamic Media Journalism}

The concept of journalism is defined as daily diaries or notes about daily events or daily newspapers; there is a common meaning between journalistic and journalism [5, p. $2]$, the gathering of news materials, processing them to publicity [6], journalism or authorship [7, p. 4] one particular form of the way humans convey messages or communication [8].

The Associated Press (AP) news agency introduced a formula for the completeness of the news, it is known as the $5 \mathrm{~W}+1 \mathrm{H}$ formula. A story is declared as a complete and feasible story if it has fulfilled the who, what, where, when, why, and how [5, p. 36]. This news writing formula helps journalists in reporting events by looking at each element in the AP formula. Lack of one or more of these predefined elements will reduce the completeness of the news.

This information technology era of journalism done through the internet is known with the term online media, cyber media, internet media, and new media [9]. Online media becomes one form of new media which is also known as online media journalistic. Media online is rapidly developed and enjoyed by the public in obtaining the information and news [7, p. 113]. The best thing from online media is able to present information faster than other mass media so that the information is always up to date. Online media can report from time to time.

The Islamic online media is basically has the same in common with the online media in general. The fundamental difference between Islamic online media and online media in general is in the Islamic thought ideology. The Islamic mindset influences the worldview, how to construct facts, how to write, and how to report facts as news. This is what makes it difference from online media in general.

\section{B. Political News Trends}

Political dimension is a magnet of media news that can revive the dynamics of a national democracy. Each media gives a portion of political news in accordance with the capacity and intensity of the media in the view of political events that occur in accordance with the ideology of the media adopted.

Online Islamic media as a media with Islamic labels certainly provides certain effects associated with the political news delivered. Islam as an ideological label tends to lead readers' opinions to approve media news.

The polarization of the trend of political news in the media can be described that media ideology, vision, and mission have a significant influence in framing political realities [10], the neutrality and objectivity of news influenced by media ideology [11], media conglomeration greatly affects the content or programs submitted to societies in which the content or program represents the economic and political interests of media owners [12], the mass media has certain trends in the coverage of international political events [13], the tendency of mass media motives emphasizes both the internal factors such as ideology and the idealism, and external factors such as market and the political situation affecting the construction of political candidates [14], the power of ownership of media companies greatly influences the content of the news [15], the prominence of news and institutions or particular figures are intended to create a certain appeal to the reader [16], during the 1999 election campaign, the Indonesian mass media generally constructed political parties like musical groups; and make their prominent characters as celebrities [17], the media and journalists have not been able to become a controlling force over the national political process. In the contrary they are even trapped into the interests of the power of the political elite [18], the spirit in public journalism is an ideal blend to present a quality news and popular news [19].

The tendency of political news that occurred in Indonesian media which has been described above shows that the media in Indonesia still has a very strong dependence on internal and external factors in which the media exists.

\section{Discourse Analysis Model by Teun A. Van Dijk}

The discourse analysis approach is used to see a production of text to know the construction of media texts that are consumed by the public. Van Dijk explains that the process of texts production involves social cognition [20, p. 224]. It means that a text does not stand alone, but it is shaped and influenced by the social structure, dominance of a particular group, and power groups in society and how the cognition (mind) and consciousness shape and influence the text.

There are six elements of discourse mentioned by Van Dijk to analyze a news: (1) Thematic Element, which is related to the general theme in a discourse (news) [21, p. 75], (2) Schematic Element is a news that hypothetically has two major schema categories. First, the summary is generally characterized by two elements namely title and lead (terrace news). Second, the story is the content of the news as a whole. The contents of this news hypothetically also have two subcategories namely the first process or course of events, while the second comment is displayed in the text [20, p. 232], (30 The semantic element, the emphasize meaning of news text [20, p. 228]. Semantics is the arise meaning from the relationship between sentences, the relationship between propositions that build a certain meaning in a text relation [21, p. 78], (4) The syntax Elements, a strategy used to display a self-character positively and display the rival negatively. A manipulation of syntax with the use of sentences such as the use of pronouns, the rules of the wording, the use of specific syntax categories, the use of active or passive sentences, clauses, use of complex sentences and so on [21, p. 82], (5) Stylistic Element, it is the way used by a speaker or writer to express their purpose by using language as a means. Style can be interpreted as a style of language [21, p. 82]. The style of 
the language includes diction or lexical choice, sentence structure, majesty and imaging, patterns, dimensions used by a writer in a literary work, and (6) Rhetorical Elements is strategies used to emphasize a message. This emphasis can be done by excessive use (hyperbolic) or long-winded. The rhetorical strategy serves to persuade audiences [21, p. 84].

The six elements of the Van Dijk model discourse above serve as a tool to analyze the trend of political news in online Islamic media. The criteria that have been determined by Van Dijk serve as a guidance in analyzing the trend of news.

\section{RESEARCH METHODS}

This study uses a critical approach that views a language is always involved in power relations, especially in shaping the subjects as well as various acts of representation in society [22]. Research analysis of Van Dijk model discourse was used to conduct this research which illustrates the trend of political news. The analytical unit in this study is the online political news of Islamic media in eramuslim.com, islampos.com, and suaraislam.com. Thematically all political news were analyzed from 5th to 11th February 2018 while another analysis focused only on yellow card political news for Jokowi on February 5th , 2018. Data collection was done through news documentation techniques, and it was analyzed using Van Dijk discourse tools which includes six structures namely; thematic, schematic, semantic, syntactic, stylistic, and rhetorical. Each unit is detailed according to the operational dimensions of discourse analysis ; topics, schemes, background, detail, intent, pre-assumption, nominalization, sentence form, coherence, pronouns, lexicon, graphics, metaphors, and expressions.

\section{RESULTS AND DisCUSSIONS}

\section{A. Online Islamic Media Profile}

\section{1) Online Islamic Media eramuslim.com}

The general leader of eramuslim.com is MM. Nasution with Editor-in-chief Riza Dirgantara. The location of the editorial address is in Perum Pratama B3 / 10 - Bogor, email; redaksi@eramuslim.com, and online address; https: //www.eramuslim.com. Tagline media eramuslim.com is the Muslim Era, Media Islam Reference. Eramuslim.com presents 13 interesting information that is showing a front platform as a whole. News Columns provide editorial, the Islamic world, Palestine, Silaturahim, National, Info Umat, Historia, and Editorial Notes. Faith Oase column presents Acts and international Dakwah.

Column of Civilization presents Shari'a Economics, Islamic thought, reflecting on Salaf, Thematic Sirah, Miracles of Qur'an and Sunnah, and Tafsir Fi Zhilalil Qur'an. Column of Focus presents Analysis, Special Reports, Do You Know, and Talks. Muslimah column presents woman talk, woman inspiration, Qur'anic Parenting, Muslimah Lifestyle, and culinary. Hikmah column presents reflective and business is Jihad). Education column and Family presents Education, Family, and Education \& Family Consultation. Column Business presents Business Information, Books Review, Product Information, Reviews, E-Market, and E-Plaza. Ustadz
Column presents Ustadz Answering, Ulama' Advice and Khutbah Jum'at. The Voice of Heaven presents ideological penetration, Light and Weighted, Toward True Life, and Invitation to Heaven. Novel Column. The Consultation column presents Healthy Clinic, Behind Conspiracy, Family Consultation, Thibbun Nabawi, Architectural Consultation, Zakat Consultation, and Endowment.

\section{2) Islamic online media islampos.com}

Islampos.com's general leaders are Irfan Fauzan and Rosadi Alibasa with editor-in-chief Rifki Mochammad Firdaus. The location of the editorial address is at Griya Ciwangi. Ruko no. 3. Rt 46/08. Ciwangi. Bungungsari. Purwakarta, email; redaksi@islampos.com and islampos@gmail.com, and online address; https://www.islampos.com. Islampos.com presents 11 interesting information columns that is a Home which shows a front platform as a whole. News Columns presents World and National. Women Column, Beginner, Family, Sirah, Did you know? Reflections, Curtains, Opinions, and Donations.

\section{3) Islamic Media onlinesuara-islam.com}

The general leader of suara-islam.com is KH Muhammad Al Khaththath with editor-in-chief HM Aru Syeiff Assadullah. The location of the editorial address is on Jl. Central Kalibata No. 3A, 2nd Floor, Pancoran, South Jakarta 12740Telp .: 021$22791447 \quad$ Fax $\quad \therefore \quad$ 021-22791447, email; redaksi_si@yahoo.com, and online address; http://suaraislam.com. Suara-islam.com presents 10 exciting information columns of Home including a front platform as a whole. The news column presents the Region, Editorial, International, Special Reports, National, and Silatrahim. Kolom Al Islam presents Akhlak (moral), Akidah (faith), Worship, and Muamalah. Family column presents Financial, Health, Parenting, and Sakinah. Consultation column presents Kiyai Answers and problem of people. Sirah Column presents Sirah Nabawiyah and Teladan (role model). Harokah and column. Muslimah column presents Beauty, Fiqh Nisa, and Rihlah. Youth column presents Students and Teens.

\section{B. Results and Discussion}

\section{1) The Trend Theme News Politics Islamic Media Online}

Thematic structure of the trend of Islamic online political media news eramuslim.com, islampos.com, and suaraislam.com on Monday / 5th - Sunday / 11th of February 2018 can be described in the table as follows: 
TABLE I. TENDENCY OF POLITICAL NEWS: ONLINE ISLAMIC MEDIA ERAMUSLIM.COM, ISLAMPOS.COM, AND SUARA-ISLAM.COM

\begin{tabular}{|c|c|c|c|c|c|c|c|c|}
\hline \multirow{3}{*}{ Day /date } & \multicolumn{6}{|c|}{ Online Islamic Media } & \multicolumn{2}{|c|}{ News Total } \\
\hline & \multicolumn{2}{|c|}{ eramuslim.com } & \multicolumn{2}{|c|}{ islampos.com } & \multicolumn{2}{|c|}{ suara-islam.com } & & \\
\hline & $\begin{array}{c}\text { Political } \\
\text { news }\end{array}$ & $\begin{array}{c}\text { Non- } \\
\text { political } \\
\text { news }\end{array}$ & $\begin{array}{c}\text { Political } \\
\text { news }\end{array}$ & $\begin{array}{c}\text { Non- } \\
\text { political } \\
\text { news }\end{array}$ & $\begin{array}{c}\text { Political } \\
\text { news }\end{array}$ & $\begin{array}{c}\text { Non- } \\
\text { politic } \\
\text { al } \\
\text { news }\end{array}$ & $\begin{array}{c}\text { Political } \\
\text { news }\end{array}$ & $\begin{array}{c}\text { Non- } \\
\text { political } \\
\text { news }\end{array}$ \\
\hline $\begin{array}{c}\text { Monday-Sunday } \\
5^{\text {th }}-11^{\text {th }} \text { February } \\
2018\end{array}$ & 68 & 35 & 46 & 75 & 22 & 16 & 136 & 126 \\
\hline Percentage (\%) & 66,02 & 33,98 & 38,02 & 61,98 & 57,89 & 42,11 & 51,91 & 48,09 \\
\hline
\end{tabular}

Eramuslim.com Media was once blocked by the Ministry of Communications and Information of the Indonesian Republic for being rated as a radically contrived media [23]. The owner of the suara-islam.com media is KH Muhammad Al Khaththath. He is a former Central administrator Hizbut Tahrir Indonesia (HTI). He is issued by HTI for being affiliated with the organization of the Forum Umat Islam (FUI) [24] .Media islampos.com in conveying the news affiliated with political party, the Prosperous Justice Party (Partai Kadilan Sejahtera (PKS) [25] and even some teams of eramuslim.com migrate to the islampos.com team [26].

Based on the above data, there is a hidden message from the media behind the trend of political news that has been constructed by eramumuslim.com, suara-islam.com, and islampos.com. The existence of media is closely related to society and influencing each other [27]. Those three Islamic online media attempt to influence the majority of Muslim readers with the construction of political messages through online media. According to Uses and Gratification theory, the media is to meet the needs of an active public, who deliberately use the media for a particular purpose [28], [29]. On the view of propaganda, the media directs the activity of news (press) oriented to the interests of government or certain groups [30].

2) The Schematic Structure of Political News Trends of Online Islamic Media

\section{a) https://www.eramuslim.com}

The schematic structure of political news trends of online islamic media of eramuslim.com on Monday, February 5, 2018 constructs the news "A Yellow Card for Jokowi, The Red Card for whom?”. The summary aspect in this news is only marked by the title, while the news lead does not exist. The title is constructed with Times New Roman font, 24 in font-size with bold text indicating an emphasis on the headline, but no news leads is made in the news.

Meanwhile, aspects of the story in this news can be seen over the course of the story that is constructed based on Fadli Zon's writing on his Twitter account. The basis of this news is
Fadli Zon's tweet via his Twitter. Then, the chronology of the events and comments on them are presented. News data are in paragraphs 1, 2 and 3.

This political news tends to construct an event from twitter's tweet data from Fadli Zon that positions himself as the government's opposition. On the other hand, the media closes it with a more neutral comment by writing the event of the Zaadit's exit process from the room. The news data are in paragraph 7.

\section{b) https://www.islampos.com}

The schematic structure of political news trends of online islamic media of islampos.com on monday, february 5, 2018 constructs the news "addressing the idea of being sent to asmat, bem ui: we have already planned to help the papuans". the summary aspect of this news is marked by the title, with leads in bold text at the beginning of the news. the title is constructed with times new roman, 24 in font-size with bold text indicating an emphasis on the headline.

The story aspects in this news can be seen over the course of the story which is constructed based on the response of President Jokowi on the yellow card given by the student in an activity. This news begins with news leads informing that President Jokowi plans to send UI students to Asmat District, Papua. This plan was then responded by the Board of BEM UI. News data are in paragraphs 1 and 2.

The News construction in this media prioritizes BEM UI response over President Jokowi's reaction that will send UI students to Asmat, Papua. Then, the flashback constructs the event of a yellow card given by the student to President Jokowi.

\section{c) http://www.suara-islam.com}

The schematic structure of political news trends of online Islamic media of voice-islam.com on Monday, February 5, 2018 constructs the news "Supporting Zaadit, Fadli Zon Makes a Yellow Card Whistle Poem ". The summary aspect of this news is marked by the title, without news leads. The title is constructed with Times New Roman, 24 in font-size with bold text that indicates an emphasis on the headline. 
The aspects of the story in this news can be seen over the course of the story which is constructed based on a poem made by Fadli Zon entitled A Yellow Card Whistle Poem that contains criticism of the government related to the economic gap and inequality of the people. Fadli Zon made the poem to support Zaadit, the chairman of BEM UI who has criticized President Jokowi by giving him a yellow card. This construct is in paragraphs 1 and 2.

Based on the data presented above, there is a tendency for news schemes to be conducted without considering the completeness aspects of the news. Completeness aspects of the news ignore the news leads and formulas of $5 \mathrm{~W} 1 \mathrm{H}$. News construction is displayed based on the opinion of political actors, not constructed based on the facts of events that occurr.

Media coverage with such a model is based on the thought of media ideology that dominates the news. Ideology can be manifested through social cognition in a social phenomenon. The essential function of ideology is as a liaison among the representation of social cognition, the process of discourse, and the existence of action [31]. It is the synergy of these three elements that can affect the news.

\section{3) The Schematic Structure of Political News Trends of Online Islamic Media}

\section{a) https://www.eramuslim.com}

The schematic structure of political news trends of online Islamic media of eramuslim.com on Monday, February 5, 2018 constructs the news of A Yellow Card for Jokowi, The Red Card for Whom?

The background element is used by journalists to justify the news that is constructed in the news in paragraph 1 . In this news, the phrase "re-commenting" has the meaning that before this news is published, Fadli Zon has once insinuated President Jokowi pertaining to the event that happened at Balairung, University of Indonesia, by rewriting the chronology of the event. This is in paragraph 5.

The detail element is related to the information control published by the media by over-displaying information that benefits themselves or that can form a good image for themselves. On the contrary, the media will display a small amount of information (even not delivered when necessary) if it is detrimental to their position. Meanwhile, the element of intent is almost similar to the element of detail so that the data displayed in this study are made into one.

From the seven paragraphs of the news, four paragraphs tend to provide a more favorable portion for the opposition party being reported, while only three paragraphs that have a tendency to use neutral sentences. News sentences that tend to be neutral are three paragraphs - paragraphs 5-7.

The presupposition element in this news is presented with a reliable source of news, namely Fadli Zon as the Vice Chairman of the House of Representatives, the vice chairman of Gerindra party, which is the government opposition party. The news data are in paragraph 1 .
The nominalization element is constructed in the news as a single thing - a criticism of President Jokowi's performance that is written in paragraphs 2 and 3.

\section{b) https://www.islampos.com}

The schematic structure of political news trends of online Islamic media of islampos.com on Monday, February 5, 2018 constructs the news of "Pertaining to the Idea of Being Sent to Asmat, BEM UI: We Have Already Planned to Help the Papuans".

The background element is used by journalists to justify the news constructed in paragraph 3 . In this news, the words "BEM UI has been planning to do concrete things ..." has the meaning that before President Jokowi sends them to Papua, BEM UI have already planned to go to Papua.

The detail elements and intent elements are displayed by islampos.com through 10 paragraphs of news. In this news, there is a tendency of the media to display information in favor of government opposition, there are 5 paragraphs of news $(1,2,3,9$ and 10) which are in favor of the opposition, while there are 5 paragraphs of news that tend to be a flashback telling the chronology of the events and that are inclined to support the opposition. Meanwhile, the news sentences having flashbacks are 5 paragraphs - paragraphs $4,5,6,7$, and 8 .

The presupposition element in this news is presented with a background of news sources from the Vice Chairman of BEM UI who responds to President Jokowi's reaction who will send him to Papua. He is Idmand Perdina in paragraph 2.

The nominalization element is constructed in the news as a single thing that is a criticism of President Jokowi's performance as described in the news data on detail elements, intentions, and presuppositions.

\section{c) http://www.suara-islam.com}

The schematic structure of political news trends of online Islamic media of voice-islam.com on Monday, February 5, 2018 constructs the news "Supporting Zaadit, Fadli Zon Creates A Yellow Card Whistle poem".

Background elements are used by journalists to justify the news constructed in the news paragraphs 1 and 2 . The voiceislam.com media constructs this news in only 2 paragraphs, the rest is filled with Fadli Zon's poems. Thus, the details, intentions, presuppositions, and nominalizations are not fully illustrated.

Based on the above data, the semantic structure shown through the background, details and intent of the news has not met the criteria of journalistic language. The language of journalism is the language used by journalists in writing the news that meets the true, actual, and important elements for the readers [32, p. 7]. The language used tends to be a tool for the self-expression (of the media) [32, p. 8] and has a tendency to put political news as opposition or criticize the government by displaying the opinions of certain political actors. 
4) The Syntactic Structure of Political News Trends of Online Islamic Media

\section{a) https://www.eramuslim.com}

The syntactic structure of political news trends of online islamic media of eramuslim.com on Monday, February 5, 2018 constructs the news A Yellow Card for Jokowi, The Red Card for whom?

The the sentence form element is marked by the sentence form of active and passive sentences. The form of active sentences in this news is reflected in paragraphs 1,4 , and 6 . The passive form is reflected in the news data of paragraph 3.

In the news are interrogative sentences that are reflected in the news headline - A Yellow Card for Jokowi, The Red Card for Whom? Giving a yellow card, one will be sent to Asmat. If he gives a red card, where will he be sent? (par.3). There is an exclamation sentence reflected in the following data: Fadli questioned where a person would be sent if he gave a red card to President Jokowi (par.2).

The coherence element is reflected in the construction of the news that connects one sentence to another. This element is reflected in the news data of paragraphs 1,3 , and 4 . In this news, no pronouns are used. This news tends to use active and passive sentence forms.

\section{b) https://www.islampos.com}

The syntactic structure of political news trends of online islamic media of islampos.com on Monday, February 5, 2018 constructs the news "Addressing the Idea of Being Sent to Asmat, BEM UI: We Have Already Planned to Help the Papuans".

The elements of sentence forms are marked by active and passive sentences. The form of active sentences in this news is reflected in the news data of paragraph 10 . Meanwhile, the form of passive sentences is reflected in the news data of paragraphs 1.3, and 9 .

This news generally contains the value of news sentences. The coherence element is reflected in the construction of the news that connects one sentence to another. This element is reflected in the news data in paragraphs $1,2,3,9$, and 10 as news that has coherence with the news or events that have occurred. Meanwhile, coherence in this news is constructed through flashback news that retells the events to support the news that tends to be oppositional in paragraphs 4,5,6,7, and 8 .

In this news, the use of pronouns is reflected in the use of the term Zaadit with the Chairman of BEM UI, and also Idmad with the Vice Chairman of BEM UI. This news tends to use passive sentence forms.

\section{c) http://www.suara-islam.com}

The syntactic structure of the political news trends of online Islamic media of voice-islam.com on Monday, February 5, 2018 constructs "Supporting Zaadit, Fadli Zon Makes A Yellow Card Whistle Poem".

The elements of sentence forms in this news tend to use passive sentences and only use two paragraphs in the news. In general, this news does not use the type of sentence, coherence, and concrete pronouns because it has only two paragraphs, and the rest contains a poem written by Fadli Zon.

5) The Stylistic Structure of the Political News Trends of Online Islamic Media.

\section{a) https://www.eramuslim.com}

In the news headlines, the media tend to choose words that contain controversial elements - A Yellow Card for Jokowi, The Red Card for whom? And also "Giving a yellow card, one will be sent to Asmat. If he gives a red card, where will he be sent? Ouch, common sense is fading in this country, " wrote Fadli, quoted from his Twitter account, @ fadlizon, Monday, (5/2) (par.3). This word choice contains ideological elements as the government opposition and reflects connotative meanings.

\section{b) https://www.islampos.com}

The lexicon or the word choice used to construct the news from islampos.com under the title "Addressing the Idea of Being Sent to Asmat, BEM UI: We Have Already Planned to Help the Papuans" prefers a word that tends to be ambiguous compared to the actual events. This news is written with a choice of words prioritizing information from BEM UI (paragraphs 1, 2, 3, 9, and 10) compared to the actual events. The reaction of the Vice-Chairman of BEM UI was made as the headline. Then, the chronology of the events was told as in paragraphs 4, 5, 6, 7, and 8 . With this kind of word choice, the media tends to position itself as the government opposition.

\section{c) http://www.suara-islam.com}

The lexicon or the word choice used to construct the media news at voice-islam.com under the title "Supporting Zaadit, Fadli Zon Makes A Yellow Card Whistle Poem" prefers a word that tends to be the government opposition. This news is written with a choice of words prioritizing information from Fadli Zon, as an interviewee who opposes the government (paragraphs 1 and 2). Fadli Zon's criticism of the government has been made the headline. The choice of the word "support" indicates the opposition's character because the one being supported is a critic of the government, in this case President Jokowi. With this kind of word choice, the media tends to position itself as the government opposition.

Based on the above data, the stylistic structure used tends to use active sentences and be in an oppositional stance to the government in accordance with the ideology of the media.

6) The Rhetorical Structure of the Political News Trends of Online Islamic Media.

\section{a) https://www.eramuslim.com}

The graphical elements are constructed through the news headlines with Times New Roman, 24 in font-size with bold 
text "A Yellow Card for Jokowi, The Red Card for Whom?". This shows the importance of the news.

The metaphoric element is constructed through the news in the third paragraph - Giving a yellow card, one will be sent to Asmat. If he Gives a red card, where will he be sent?. The phrase "red card" is a form of exaggerative metaphor, that is, an abstract place that signifies a further place. The expression element is shown through the news images of Zaadit, yellow card, and President Jokowi.

\section{b) https://www.islampos.com}

The graphical element is constructed through the news headline in Times New Roman, 24 in font-size with bold text "Addressing the Idea of Being Sent to Asmat, BEM UI: We Have Already Planned to Help the Papuans "which shows the importance of the news.

The metaphoric element is constructed through the news in the tenth paragraph - "This is our concrete step for our friends in Papua," he said. The phrase "our friends in Papua" is a metaphor meaning that Papuans have close relationships, kinship, harmony, brotherhood, and intimacy with UI students even though they are far from each other. The expression element is shown through the news images of Zaadit, yellow card, and President Jokowi.

\section{c) http://www.suara-islam.com}

The graphical element is constructed through the news headline with Times New Roman, 24 in font-size with bold text "Supporting Zaadit, Fadli Zon makes A Yellow Card Whistle poem" which shows the importance of the news.

The metaphorical element is constructed through the poem in the news in paragraph 3 . This poem is a metaphorical form meaning a criticism of the government for its performance that has been done, as well as a form of support to Zaadit who has given a yellow card to President Jokowi. The expression element is shown through the news pictures of Fadli Zon reading his poem for Zaadit.

Based on the above data, the rhetorical structure displayed through the metaphor has a different perspective of the news construction. Moreover, voice-islam.com only shows two paragraphs of the news, and the rest is constructed through Fadli Zon's poem. Its graphical aspect also takes a different viewpoint among the three online Islamic media. In addition, voice-islam.com constructs Fadli Zon's picture reading the poem.

\section{CONCLUSION}

Politics as a media issue has always been interesting to study. Political dimension in all its angles can provide a wide space for the media to construct political events that occur. The media's construction of politics is heavily influenced by the media ideology. Interestingly, the online Islamic media also contribute in the discourse of political news. For the majority of Indonesian Muslim communities, the label of online Islamic media provides a special meaning for Muslim readers. This Islamic label is exploited by the media to convey its political messages in secret. The critical readers are able to select the correct and good news. However, for the less critical readers, they can be unconsciously and greatly affected by the effects of the media news.

This research is extremely urgent to dissect the construction of online Islamic media eramuslim.com, islampos.com, and voice-islam.com; and to find some unique findings in the realm of online Islamic media journalism, that is, the tendency of the media to report national politics of $51.91 \%$ and non-political news of $48.09 \%$. The news schemes are displayed without leads and the news stories are more likely to be based on opinions rather than facts. The semantic structure has a tendency to put political news as the opposition or criticize the government by displaying the opinion of certain political actors. The syntactic structure is displayed through the form of active sentences that continuously questions the government policy through the political actors without considering the 5W $+1 \mathrm{H}$ aspects in the news. The stylistic structure tends to use active sentences and be in an oppositional stance to the government. The rhetorical structure tends to use emphasis by displaying pictures or images as a form of political news affirmation that is delivered through the headline with bold and large text.

\section{REFERENCES}

[1] B. Lavanya, B. S. Shylaja, and M. S. Santhosh MS, "Industry 4.0: The Fourth Industrial Revolution,” Int. J. of Sci., Eng. and Technol. Res. (IJSETR), vol. 6, no. 6, June 2017, ISSN: 2278 -7798.

[2] D. Domingo and H. Heikkilä, "Media Accountability Practices in Online News Media," in The Handbook of Global Online Journalism, E. Siapera and A. Veglis. USA: John Wiley \& Sons, Inc., 2012, p. 27.

[3] R. Harun and Sumarno, Komunikasi Politik Sebagai Suatu Pengantar [Political Comunication as an Introduction]. Bandung: Mandar Maju, 2006, p. 3.

[4] N. Ali, Peradaban Komunikasi Politik, Potret Manusia Indonesia [Political Communication Civilization, A Portrait of Indonesian People]. Bandung: Remaja Rosdakarya, 1999, p. 132

[5] S. W. Barus, Jurnalistik: Petunjuk Teknis Menulis Berita [Journalism: Technical Instructions for Writing News]. Jakarta: Penerbit Erlangga, 2010

[6] R. Harianto, Dasar Jurnalistik [Basic Journalism]. Surabaya: UINSA Press, 2014, p. 3.

[7] I. Suryawati, Jurnalistik: Suatu Pengantar, Teori dan Praktek [Journalism: An Introduction, Theory, and Practice]. Bogor: Ghalia Indonesia, 2014

[8] H. Daulay, Jurnalistik dan Kebebasan Pers [Journalism and Freedom of the Press]. Bandung: PT Remaja Rosydakarya, 2016, p. 1.

[9] A. Syamsul and M. Romli, Jurnalistik Online: Panduan Praktis Mengelola Media Online [Online Journalism: Practical Guidance on Managing Online Media]. Bandung: Nuansa Cendekia, 2012, p. 30.

[10] N. Y. Sapahuma, "Realitas Politik dalam Media Massa: Konstruksi Pemberitaan Media Massa Seputar 100 Hari Pemerintahan Jokowi-JK [Political Reality in Mass Media: Mass Media News Construction on the First 100 Day of Jokowi-JK Government]”, POLITIKA, vol. 6, no.1, April 2015.

[11] B. M. Sihombing, "Pembingkaian Berita Politik dalam Pemilihan Kepala Daerah: Analisis Framing Berita Pemilihan Walikota Pekanbaru di Surat Kabar Tribun Pekanbaru dan Riau Pos [Political News Framing in Local Election: News Framing Analysis in Pekanbaru Mayor Election in Tribun Pekanbaru and Riau Pos Newspaper],” JOM FISIP, vol. 4, no. 2, October 2017.

[12] J. G. Pembayun, "Konglomerasi Media dan Dampaknya pada Pilpres 2014 [Media Conglomeration and its Effects on 2014 Presidential Election]”, Jurn. Inter., vol. 4, no. 2, pp. 109-116, July 2015. 
[13] N. Andrianti, "Peran Media Massa Nasional dalam Politik Internasional [Role of National Mass Media in International Politics],” Jurn. Infor. Kaj. Ilm. Komun., vol. 45, no. 1, June 2015.

[14] H. Yodiansyah, "Komunikasi Politik Media Surat Kabar dalam Studi Pesan Realitas Politik Pada Media Cetak Riau Pos dan Tribun Pekanbaru [Political Communication of Newspaper Media in the Study of Political Reality Message in Printed Media of Riau Pos and Tribun Pekanbaru],” Jurn. Kaj. Komun., vol. 5, no. 1, pp. 11-30, June 2017.

[15] F. Diba, “Analisis Framing pada Pemberitaan Politik Partai Hanura di Media Online Sindonews [Framing Analysis in Political News of Hanura Party in Online Media of Sindonews],” eJournal Ilm. Komun., vol. 2, no. 3, pp. 165-176, 2014

[16] L. E. Pratiwi, "Konstruksi Realitas dalam Berita Politik di Media Cetak Lokal; Studi Analisis Wacana terhadap Teks Berita Seputar Kampanye SBY-Boediono pada Pilpres 2009 di Harian Umum Solopos Periode 1 Juni 2009 - 4 Juli 2009 [Reality Construction in Political News in Local Printed Media: Discourse Analysis Study towards News Text about SBY-Boediono Campaign on 2009 Presidential Election in Solopos Daily Newspaper, June 1st 2009 - July 4th 2009].”

[17] I. Hamad, “Konstruksi Realitas Politik dalam Media Massa: Studi Pesan Politik dalam Media Cetak pada Masa Pemilu 1999 [Political Reality Construction in Mass Media: Political Message Study on Printed Media during 1999 General Election],” Makara, Sos. Hum., vol. 8, no. 1, April 2004

[18] Masduki, “Jurnalisme Politik: Keberpihakan Media dalam Pemilu 2004 [Political Journalism: Media Alignments in 2004 General Election]”, Jurn. Ilmu Sos. dan Ilmu Pol., vol. 8, no. 1, pp. 75-90, July 2004, ISSN 1470-4946.

[19] R. D. Lestari, “Quality News dan Popular News Sebagai Trend Pemberitaan Media Online [Quality News and Popular News as Online Media's News Trends],” Jurnal Channel, vol. 5, no. 1, pp. 83-94, April 2017, ISSN: 2338-9176.

[20] Eriyanto, Analisis Wacana: Pengantar Analisis Teks Media [Discourse Analysis: Media Text Analytical Introduction]. Yogyakarta: Lkis, 2003.

[21] A. Sobur, Analisis Teks Media [Media Text Analysis]. Bandung: Remaja Rosyda Karya, 2001.
[22] A. Badara, Analisis Wacana: Teori, Metode, dan Penerapannya pada Wacana Media [Discourse Analysis: Theories, Methods, and its Applications on Media Discourse]. Jakarta: Kencana, 2012, p. 25.

[23] Ibnu, "Situs Eramuslim Diblokir Lagi [Eramuslim Site Blocked Again]," bersamadakwah.net, January 28, 2016. [Online]. Available: http://bersamadakwah.net/situs-eramuslim-diblokir-lagi.

[24] "Siapa Pemilik Situs Suara Islam atau Suara-Islam.com? [Who is the Owner of Suara Islam Website or suara-islam.com?]” muslimedianews, April 13, $2015 . \quad$ [Online]. Available: https://muslimedianews.wordpress.com/2015/04/13/siapa-pemilik-situssuara-islam-atau-suara-islam-com

[25] “Tim Cyber NU: Ini Daftar Website Kelompok-kelompok Radikal [NU Cyber Team: This is the List of Radical Groups Websites],” May 30, 2017. [Online]. Available: http://www.suaraislam.co/tim-cyber-nu-inidaftar-website-kelompok-kelompok-radikal/.

[26] "Bongkar Peringkat Situs Islam di Indonesia, Mau Tau Siapa Saja Mereka? [Reveals Indonesian's Islamic Site Ranks, Want to Know Who are they?]" October 20, 2013. [Online]. Available: http://www.voaislam.com/read/smart-teen/2013/10/20/27157/bongkar-peringkat-situsislam-di-indonesia-mau-tau-siapa-saja-mereka/\#sthash.qMms01Pn.dpbs.

[27] F. Rahmadi, Perbandingan Sistem Pers [Press System Comparison]. Jakarta: Gramedia, 1985, p. 5

[28] O. U. Effendy, Ilmu, Teori, dan Filsafat Komunikasi [Sciences, Theories, and Philosophy of Communication. Bandung: Remaja Rosyda Karya, 2000, p. 289

[29] A. S. Tan, Mass Communication Theories and Research. Ohio: Grid Publishing, 1981, p. 298.

[30] A. E. Siregar, "Industri dan Pasar Pers Indonesia [Industry and Market of Indonesian Press],” Kompas, p. 5, Nov. 16, 1987.

[31] U. Rusadi, Kajian Media: Isu Ideologis dalam Perspektif, Teori, dan Metode [Media Studies: Ideological Issue in Perspective, Theory, and Method]. Jakarta: PT. RajaGrafindo Persada, 2015, p. 76.

[32] A. S. H. Sumadiria, Bahasa Jurnalistik: Panduan Praktis Penulis dan Jurnalis [Journalism Language: Practical Guide for Writers and Journalist]. Bandung: Simbiosa Rekatama Media, 2010. 